\title{
Reasons Analysis of Chinese Urban Consumers Opposing Genetically Modified Food-An Empirical Analysis based on a Metropolitan Representative
}

\author{
Yue $\mathrm{Ma}^{1}$ \\ ${ }^{1}$ Graduate School of Chinese Academy of Social Sciences, Beijing, China \\ Correspondence: Yue Ma, Graduate School of Chinese Academy of Social Science, Liang Xiang Distract, Beijing, \\ China. Tel: 86-183-1108-5605.E-mail: mayue_0105@126.com
}

Received: January 15, 2014 Accepted: January 30, $2014 \quad$ Online Published: April 14, 2014

doi:10.5430/sass.v1n2p11 URL: http://dx.doi.org/10.5430/sass.v1n2p11

\begin{abstract}
Since genetically modified food appeared in Chinese market, it has become a big dispute. Scientific experiments has proved that genetically modified food possesses many advantages such as insect resistance, herbicide tolerance and disease resistance. However it is a fact that many Chinese consumers prefer conventional food to genetically modified food when they go to supermarket. Through collecting and analysis of the information, the reasons were attributed to four aspects. Firstly, transgenic technology itself existed high risk. Secondly, human health may be threatened by them because of the uncertainty. Thirdly, perhaps genetically modified food may bring environment hazards. Finally, some companies which researched genetically modified food in order to ensure a big profit return regardless of corporate social responsibility.
\end{abstract}

Keywords: Transgenosis, Safety issues, Genetically Modified food, Human Health, Environment Hazards, Company Profit, Food Safety

\section{Introduction}

This essay will examine the facing problems genetically modified food in China and find out the true reasons why so many Chinese people oppose it. Firstly, it will issue the background to the problems, starting with some events involved genetically modified food. Secondly, it will explain the concept of the genetically modified food. Then, it will review the literatures on this subject at home and aboard. After this, it will explain how to design the measurement. Then, it will draw some results according to questionnaires. After this, there will be an analysis of the reasons. The reasons why so many Chinese people reject genetically modified food probably were attributed to four aspects. Finally, there will be discussion, followed by recommendation, references and appendices.

\section{Method}

This paper will adopt empiricism methodology. In order to investigate the safety issues of genetically modified food in urban consumers, a questionnaire including twenty-five questions was designed some expected results may be concluded through the analysis of the samples. The questions were concerned with the residents' basic personal information and their opinions toward the opinions of genetically modified food. Their opinions gave important positions to acquire their true ideas. There were twenty-five questions with two exceptions, each involved ticking items on a list. Among the questions, five basic questions were front, including sex, age, occupation, income and education background. Then, there were five "Yes or No" questions and seven "making choice on a scale" questions which range from strongly supporting to strongly opposing. Finally, there were seven "Question- word questions" and one "open-ended questions" was at the end.

\section{Background}

China returned 545000 tons of genetically modified crops from America recently, while American government was 
urgent that Chinese government should permit to import a bulk of genetically modified food from America. A scandal "Golden Rice" in Hunan province which was experimented by American company was exposed by Chinese government, which enormously caused Chinese people's anger. When some famous scientists in China claimed to support genetically modified food, more and more Chinese people showed their objections. Meanwhile, a famous compere, for example, Cui Yongyuan went to America to investigate the truth and popularity of genetically modified food in America. In addition, some news from overseas experiments has pointed out that some genetically modified foods contained poison and had harm to human being's health. There were also news that many foreign countries for example European Union must proceed a test on genetically modified food. If components of transgenosis are detected, they will prohibit any import of foods from China. Thus, according to the news from internet, television, magazine, newspaper, not only was genetically modified food told widely, but also was opposed by most Chinese people.

The term of genetically modified food may be defined as a new plant which has been modified in the laboratory through the latest molecular biology techniques to enhance desired traits such as increased resistance to herbicides or improved nutritional content. Genetically modified food is different from conventional food. For example, plant geneticists can isolate a gene responsible for drought tolerance. Then, the new genetically modified plant will gain drought tolerance as well. Not only can genes be transferred from one plant to another, but genes from non-plant organisms also can be used. The best known example of this is the use of B.t. genes in corn and other crops. B.t., or Bacillus thuringiensis, which is a naturally occurring bacterium that produces crystal proteins that are lethal to insect larvae. B.t. crystal protein genes have been transferred into corn, enabling the corn to produce its own pesticides against insects such.

Thus, it appears that genetically modified food has many advantages such as insect resistance, herbicide tolerance, disease resistance, cold tolerance,drought tolerance, salinity tolerance and nutrition. Some religious organizations, public interest groups, professional associations and other scientists and government officials have all raised concerns about genetically modified food. The world population has grown rapidly recent years and food crisis has become a big problem in the world. Inadequate food supply for this booming population is going to be a major challenge in the years to come. Even if China is a big country of agriculture, it still exists food crisis, Chinese agriculture still lags behind other departments and some Chinese in remote villages are still tripped in starvation and malnutrition. It seems that if Chines peasants plant more genetically modified food, they probably gain more food, earn more money and change their bad situations. However, a study published in Nature showed that pollen from B.t. corn gave birth to high mortality rates in monarch butterfly caterpillars. As Whitman(2000) released that it was not simply to know whether genetically modified crops were security for human or animal consumption, which reflected in the ongoing scientific controversy surrounding its safety assessment. Moreover, Muir and Howare (1999) also showed that bring the production of transgenic organisms into natural populations may result in ecological danger, for example, species extinction.

More and more consumers suspected the safety of genetically modified food. It is crucial to find out the main reasons. According to the main reasons, some solutions may be enacted. Firstly, perhaps scientists may further the research of genetically modified food, Secondly, Chinese government may be more cautious on the import of genetically modified food.

\section{Review of Literature}

Since gene was discovered, there are much research on gene technology. Especially, it is a revolution that transgenic technology was invented. From that time, many scientists struggled to apply it to other fields, especially crops. Now, it seems that their goal is achieved. But, people's worries appeared as well. Many people showed doubt and disturbance. Through some literature or news, it seems that most concerns about genetically modified food falls into four categories: transgene technology itself, human health, environmental hazards, economic concerns.

Firstly, while traditional produces to evaluate food security examine the effects of individual chemicals on animal species, these approaches are insufficient for researching the safety of genetically modified food. As Schauzu (2000) pointed out that the security of evaluation of genetically modified relies on the conception of substantially equivalence which ought to be demonstrated between the genetically modified food and its traditional food counterpart. This was confirmed by Clydesdale (1996) that it was important that consumption of any food might present some risks or hazards due to the presence of proteins or other naturally occurring chemicals that might cause allergies or other harmful effects. "The most common allergy-causing food are cow's milk, eggs, fish, shellfish, tree nuts, wheat, peanuts, and soybeans". (Clydesdale 1996) Unfortunately, as Lachmann (1990) stated that researchers 
were unable to form firm conclusions because of inadequacy of genetically modified control and limitation of the number of animals involved. It can be included that many persons including some scientists suspected the safety of genetically modified food.

Secondly, some reports from laboratories showed that genetically modified food probable does harm to the health of human beings. A report by the Canadian Royal Society stated that if there were not deeply biological examination of genetically modified food, genetically modified food may expose Canadians to potential health risks of toxic and allergic reactions. Neither did the British Medical Association accept that all genetically modified food are safe. In the United Kingdom, the Medical Research Council also stated that any conclusions upon the safety of introducing genetically modified food material into the United Kingdom was premature as there were insufficient evidences to inform the decision-making processes at present. Therefore, it was not surprising that the majority of British consumers thought that genetically modified food were unsafe. Fortunately, their government has realized and forbidden the import of genetically modified food. Through investigation, Pusztai and Bardocz (2011) found that most consumers in Europe demanded transparent and independent safety testing of all genetically modified food. Salanti (2005) also argued that genetic engineering was not a perfect technology. The transfer of gene might result in unpredictable influences, such as new plant toxins. There are many examples to support this. "According to a 1999 study, genetically modified potatoes weakened rats's immune systems and negatively affected their kidneys, thymuses, spleens, gastrointestinal tracts and brains". (Anna 2005) It can include that if someone eats genetically modified food, he or she might eat much toxins contained in food. So, the health of people may probably damaged by the genetically modified food.

Thirdly, there are many data showed that genetically modified food might be hazards to environment. According to the Would Health Organization, there was a high risk that referred to the transfer of transgenes from genetically modified food to conventional plants or species in the wild. John (2010) showed that the foreign genes might probably contaminate some strange species, which could radically change entire ecosystems of one country. Besides, genetically modified food may probably do harms to non-target organisms. For example, a reported published in Nature in 1999 stated that some genetically modified food could result in high mortality rates among monarch butterfly caterpillars. Once ecosystem was damaged, it probably needed more time, more money and more power to manage.

Finally, some consumers showed that people who invested on genetically modified food were probably involved in economic concerns. Some critics of genetically modified food were that monetary interests were a driving factor in the development of them and some biotech companies may want to monopolize the agriculture. For example, in America, almost biotechnology companies totally carried out their own safety assessment of the genetically modified food which they wanted to be released commercially. As Tiffany (2012) showed that " the agrichemical farm industry seeks to control our food system by keeping us in the dark as to what, exactly, is in our food and being released into our environment." if it is true, genetically modified food may be a disaster.

\section{Statement of the Problem}

The safety issues of genetically modified food in urban consumers are based on current events food safety in China. Some scientists and experiments have proved that genetically modified food have many advantages, for example, insect resistance, herbicide tolerance and disease resistance. It should know that China is a big country of agriculture. If China spread genetically modified food, she will get much benefits. However, food security is also an important issue in China, including genetically modified food, which is similar with foreign countries such as America, British and Canada. For example, European Union has forbidden the import of genetically modified food from other countries. The above news has shocked most Chinese people. Thus, it can be seen that a lot of news from internet, television, magazine, newspaper have showed Chinese objections towards genetically modified food. So, it is significant to investigate the deep reasons. On the one hand, the worries of Chinese consumers towards the genetically modified food should be realized and respected. On the other hand, if genetically modified food exists a lot of uncertainty and risks, the government should take some appropriate measures to enhance the supervision of it in the further.

\section{Results}

Through collecting and analysis of the questionnaires, the main findings were as follows. The average of age of respondents was approximate twenty-seven years old. All their occupations were postgraduates with low income, 
about two thousands yuan each month. Before this survey, $99 \%$ of the students admitted that they knew the genetically modified food, most of whom had known genetically modified food through television, internet and magazine. All most of respondents could recognize the genetically modified food such as soybean, corn and rice. $75 \%$ of the students said that they emphasized on the label of genetically modified food when they shopped in the market. $100 \%$ of the students selected the traditional food instead of genetically modified food. The security of genetically modified food was worried by $80 \%$ of the students, $87 \%$ stated that America probably implemented the double standards of genetically modified food in the world and $94 \%$ of the student did not except that China produced or imported genetically modified food in the future.

Then, refer to the environment hazards which genetically modified food might bring, $60 \%$ of respondents showed that genetically modified food would cause a very bad influence on surroundings. Nobody admitted there was not any bad effects of genetically modified food towards environment. More $66 \%$ pointed out genetically modified food probably had very harmful to the healthy of human being as well compared with supporting $7 \%$. In addition, $60 \%$ of the students were very angry with American scientists' genetically modified food experiments of "Golden Rice" to Chinese children in Hunan province. $73 \%$ of the students considered that some companies researching on genetically modified food were probably eager to gain more money instead of well-fare of human beings.

Next, most respondents showed genetically modified food had some advantages, for instance, low price, insect-resistent and higher quantity. $100 \%$ deemed that Chinese government lacked supervision of genetically modified food. With regard to the most harmful influence of genetically modified food, the comprehensive uncertainty was chosen by $73 \%$ of the students.

Finally, facing with open-ended questions, most respondents stated that genetically modified food should cause people's attention. Before specific assessment of the security of genetically modified food, it had better not to be planted or imported. Government should enhance the supervision of genetically modified food.

\section{Conclusion}

According to the results of the survey obtained from the questionnaire, it was easy to reach some definite conclusions and it can be concluded that safety issues of genetically modified food in urban consumers may probably attributed to the following several factors. Firstly, genetically modified food itself probably exists high risk and uncertainty in the future, which caused many Chinese people's worries. Because most respondents believed that it seemed that there were no totally evidences to prove genetically modified food's security. Then, most people admitted that genetically modified food may bring lethal effects towards environment and human beings. Next, most people suspected the purpose of companies researching genetically modified food. Because, two-thirds hold that enterprises producing genetically modified food mainly pursued profits without concerning with some potential hazards. Finally, Chinese government probably failed to hold adequate regulations of genetically modified food.

On the whole, the safety issues of genetically modified food probably were attributed to genetically modified itself, harmful influence towards surroundings and human beings, doubting the purpose of producing genetically modified food companies and lack of supervision of Chinese government.

\section{Discussion}

The predicted goals were achieved and the results were approximately the same to the hypothesis of the beginning. It is a fact that many Chinese people oppose genetically modified food, which is roundly similar to the western research on genetically modified food. However, there are few disadvantages of this paper. For example, questionnaires were limited with only twenty- five questions which did not certainly include all informations about opinions. Besides, because of the limitation of knowledge, some mistakes probably were made in designing the questionnaires. Thus, there are need more tasks in the future.

\section{Recommendations}

According to the outcomes of the survey and analysis, the following recommendations may be helpful for the further related research on this topic. As far as genetically modified food appears in Chinese market, it must be an hot topic. Thus, there are more tasks to be done. Firstly, it is of importance for us to investigate more residents to ensure that number of respondents is sufficient. Because big samples may reduce errors caused by small samples.Next, the recommendation is that professional questionnaires should be involved in order to get more and true information. 
The professionals not only may know the design skills of the questionnaire quite well, but may know how to make the respondents to provide more factual information. Finally, some people who lived in rural areas should be investigated about the opinions of genetically modified food.

The safety issues of genetically modified food are complex. So, some issue-related tasks should be done according to current situations and the solutions can be classified four dimensions. Firstly, for some scientists, they should research deeply the transgenic technology oneself and should take further experiments before transplanting genetically modified species. Then, for the government, National Food Administration should tested the security of using genetically modified food. Before genetically modified food can be certified healthy and safe towards environment and human beings, it had better not to spread the planting. Next, some companies investing much money on research of genetically modified food should consider benefits of others other than themselves. They should consider the responsible of morality. Finally, because there are much illegal and smuggled genetically modified food in Chinese market, Chinese government must supervise strongly the import and planting of genetically modified food.

Most Chinese urban consumers suspected the safety of Genetically modified food. Reasons are probably attributed to, such as, transgenic technology itself, environment hazards, human health and doubting of companies researching genetically modified food. The question is complicate. Thus, there are more tasks to be done in the future.

\section{Acknowledgments}

There are many people to whom i owe gratitude for their support during the course of writing this paper. Firstly, I wish to thank my English teacher Edwin who works in the Graduate School of Chinese Academy of Social Science. He gave me a lot of advices in writing this paper. Secondly, i give my sincere thanks to my classmates. The questionnaires were finished because of their helps. Finally, i give my sincere thanks to all people who support and encourage me during the writing of paper.

\section{References}

Carl, C. K., \& Gallegos, L. K. (2006). Safety of Genetically Engineered Food. Agricultural biotechnology in California series, 8180(12), 1-5.

Dona, A., \& Arvanitoyannis, I. S. (2009). Health Risks of Genetically Modified food. Critical Reviews in Food Science and Nutrition, 49(2), 164-175.

Muir, W. M., \& Howard, R. D. (1999). Possible ecological risks of transgenic organism release when transgenes affect mating success: Sexual selection and the Trojan gene hypothesis. ECOLOGY, 96(24), 13853-13856.

Pusztai, A., \& Bardocz, S. (2011). Potential Health Effects of food Derived from Genetically Modified Plants: What Are the Issues? Malaysia: Third World Network. 